\title{
Power generation estimation from wheat straw in Mexico
}

\author{
C. García ${ }^{1}$, G. Montero ${ }^{1}$, M. Coronado ${ }^{1}$, R. Torres ${ }^{1}$, \\ A. M. Vázquez ${ }^{2}$, J. R. Ayala ${ }^{1}$, J. A. León ${ }^{1} \&$ C. A. Sagaste ${ }^{1}$ \\ ${ }^{1}$ Institute of Engineering, Autonomous University of Baja California, \\ Mexico \\ ${ }^{2}$ School of Engineering and Business, Guadalupe Victoria, \\ Autonomous University of Baja California, Mexico
}

\begin{abstract}
By 2013, the wheat grain harvested area in Mexico was 683,044.42 ha, which represents $3.06 \%$ of the national area for agricultural purposes. At the end of each agricultural cycle, wheat straw is generated as biomass waste. Mexican farmers burn the wheat straw in the same place where it is generated, in order to clean and prepare the land for the next harvest. Hence, the aim of this work was to determine the amount of wheat straw generated at a national level, identify the states with high biomass potential, and estimate the energy potential. It was estimated that 4,612,950.23 t of wheat straw are generated in Mexico. Sonora and Baja California generated $61.69 \%$ of the wheat straw. The results highlighted $69.19 \mathrm{PJ}$ per agricultural cycle, equivalent to $18.24 \%$ of the biomass energy share reported in Mexico's National Energy Balance, by 2013. The option to use this energy for electricity generation in a biomass power plant was assessed. It could potentially supply a national biopower industry with a total installed capacity of $728.05 \mathrm{MW}$. The waste biomass has been one of the best options to replace fossil fuel resources and is a sustainable activity that does not deplete future resources.
\end{abstract}

Keywords: wheat straw, biomass, power generation, biofuel feedstock.

\section{Introduction}

Wheat is one of the foods most in demand with global consumption per capita; $56.8 \mathrm{~kg} /$ year in 2012/13 [1]. According to FAO [2], wheat crops worldwide were 
of 690 million t. These data highlights the fact that wheat is one of the largest grain productions in the world, because of its great importance for human consumption. Wheat production in Mexico, preceded by corn and bean, is the fourth grain grown for the diet of more than 118 million inhabitants [3]. By 2013 , the cultivated surface was of $683,044.42$ ha, with a production of $3,357,306.9$ t [4].

Once the wheat is harvested, around the $15 \%$ of wheat straw generated is used for the following purposes:

- Food for cattle.

- Soil improver.

- Fiber for production of construction material.

The rest of wheat straw is open burned in situ. Wheat straw is generated in different states of Mexico where wheat is grown, and represents a residual biomass option that results attractive, due to its high availability and energy potential. The burning of wheat straw is a common practice used by Mexican farmers since it reduces costs for land preparation for the next agricultural cycle. It avoids spread of pests and diseases in future crops. This practice is made without any control, which damages the agricultural land, because it eliminates beneficial microorganisms [5], nutrients, and organic material necessary for moisture retention. Besides, it endangers others crops as well as the integrity and health of the inhabitants, which is predominantly associated with respiratory problems [6].

Biomass has been one of the best options to replace fossil fuel resources. It includes agricultural residues, animal manure, wood wastes from forestry and industry, residues from food and paper industries, municipal green wastes, etc. Agricultural residues are generated after each harvesting cycle of commodity crops. A fraction of the remaining stalks and biomass material left on the ground could be collected and used for energy generation purposes [7]. Biomass can be used directly, e.g. burning wood for heating and cooking, or indirectly by converting it into a liquid or gaseous fuel.

The net energy available from biomass ranges from 8 to $20 \mathrm{MJ} / \mathrm{kg}$, compared to the $27 \mathrm{MJ} / \mathrm{kg}$ of coal [8]. Energy crops have larger potential, but they are also more expensive. Technologies, power cost and heat generation from biomass depend on feedstock quality, availability, transportation, cost and power plant size. If sufficient biomass is available, biopower plants would be a clean and reliable power source suitable for a base-load service [9]. The biomass for energy use from forestry practices or crops on marginal land are a sustainable alternative, but may not have the potential to provide enough stocks [10].

Among the many reasons for increasing biomass utilization, environmental and health benefits are the most important. Compared with coal, biomass feedstock's have lower levels of sulphur. Therefore, substitution of coal by using biomass in power plants has the effect of reducing $\mathrm{SO}_{2}$ emissions. Demonstration tests have shown that biomass co-firing with coal can also lead to lower $\mathrm{NO}_{\mathrm{x}} \mathrm{SO}_{2}$ emissions [11]. Perhaps, the most significant environmental benefit of biomass is 
the reduction of $\mathrm{CO}_{2}$ emissions; it is not precisely a net zero emission process in a life-cycle, because there are $\mathrm{CO}_{2}$ emissions associated with harvesting, transportation, and feed preparation operations [7].

Biomass for electricity generation is treated in four ways: (a) new dedicated biomass or biomass gasification, (b) existing and new plants that co-fire biomass with coal, (c) existing plants that combust biomass directly in an open-loop process, also known as Biomass Power Plant (BPP), and (d) use of biomass in industrial cogeneration applications [12]. The BPP is the technology reference in this paper, this power plant use technology that is very similar to the one used in coal-fired power plants.

The electricity is produced by biomass combustion, and use two-fluids in the system, where the heat is exchanged between the flue gases and water, to produce high-pressure water steam. This steam drives a steam turbine, and then spins a generator that converts the mechanical energy into electricity (as is illustrated in fig. 1) [13].

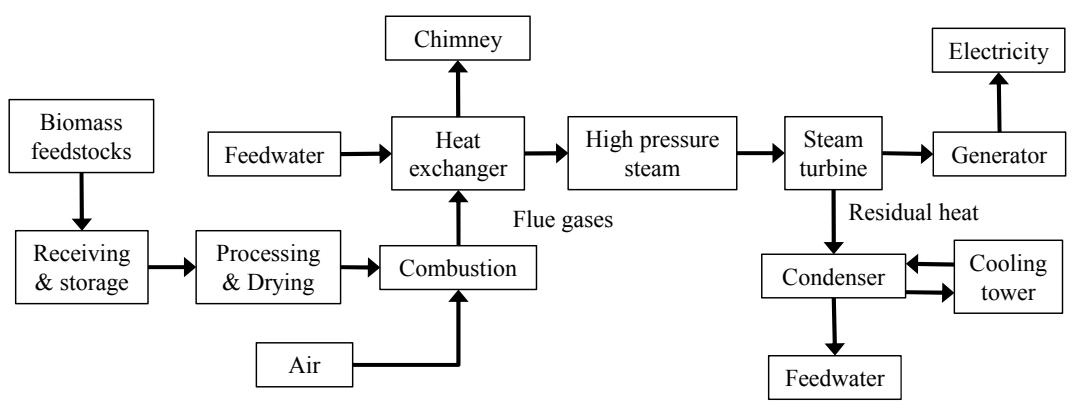

Figure 1: Biomass power process flow diagram.

Biomass plants have increased in popularity e.g. facilities with sugarcane and wheat straw processing plants. Biomass power plants are growing, expanding rapidly as the costs of fossil fuels rise, and the demand of energy is increasing. A disadvantage of these plants is that they cannot ensure the supply and storage of feedstock. Biomass energy has a number of advantages over conventional forms of energy and in some cases, depending on the feedstock, can be generated at competitive cost vs. fossil fuels. Biomass energy also leads to higher energy security, because biomass is almost always constant locally.

The steam Rankine cycle is referred to as a power cycle that includes the necessary equipment to convert the heat contained in a boiler steam into electrical energy. For the purposes of the biopower model, a Rankine cycle and an electric generator were considered. Many existing biomass power plants use a combined heat and power approach, where some of the steam is directly used in industrial processes rather than generating electricity, increasing the overall efficiency of the process [14]. 


\section{Materials and methods}

The framework of this study followed four main steps. The first step consisted of identifying the participation of wheat crop in Mexican agriculture and ranking wheat with the main crops. In a second step, the availability of wheat straw at national level was estimated. Then, the geographical location was identified on a developed map based on the available biomass. And finally, considering the energy content of wheat straw, the maximum theoretical potential of electricity generation was calculated.

\subsection{Data source}

The statistical information system of agricultural crops was consulted; it is available in the Information Service Agrifood and Fisheries (SIAP by its acronym in Spanish) in the classification of Statistical Yearbook of the Agricultural Production [4]. The research was limited to major crops of wheat in all States of Mexico with the latest information corresponding to 2013.

The information of generation rate of wheat straw, conversion efficiency, and electricity generation were taken from current scientific literature, as described as follows. The calculations of the present work are based on all wheat straw generated in agricultural fields in Mexico.

The Residue Generation Index $\left(\mathrm{I}_{\mathrm{r}}\right)$ is defined as the ratio of the dry weight of residues produced to the total cultivated area, and is derived from recent literature yields. The $I_{r}$ was taken from SENER [15] corresponding to 7.3 ton/ha of wheat straw, despite the different varieties grown in Mexico. The low heat value (LHV) of wheat straw has been estimated by McKendry [16] in $17,300 \mathrm{MJ} / \mathrm{t}$. In the current work, the LHV considered was $15,000 \mathrm{MJ} / \mathrm{t}$, because the wheat straw generated in Mexico has not been characterized.

Energy contained in this residue can be used through biomass combustion in a power generation plant. The efficiency reported in the literature is between 33 and $35 \%$. [9, 16-18]. Nevertheless, conversion of $30 \%$ and a time of operation plant of 7,920 hours were considered, conservatively in the current evaluation.

According to eqn (1), the wheat straw generation was estimated:

$$
\mathrm{Q}_{\mathrm{ws}}=\mathrm{S}_{\mathrm{w}} \mathrm{I}_{\mathrm{r}}
$$

where $Q_{w s}$ is the quantity of wheat straw $(t), S_{w}$ is the surface of wheat (ha), and $I_{r}$ is the residue generation index ( $\left.t / h a\right)$.

For the determination of wheat straw energy potential, the eqn (2) was used:

$$
\mathrm{E}_{\mathrm{p}}=\left(1000 \mathrm{Q}_{\mathrm{ws}}\right) \mathrm{LHV}
$$

where $E_{p}$ is the energy potential $(\mathrm{MJ})$ and LHV is the low heat value $(\mathrm{MJ} / \mathrm{t})$. The calculation of power generation capacity was based on eqn (3):

$$
\mathrm{P}_{\mathrm{gc}}=\left(\mathrm{E}_{\mathrm{p}} / \mathrm{T}_{\mathrm{op}}\right) \mathrm{E}_{\mathrm{f}}
$$

where $P_{g c}$ is the power generation capacity (MW), $T_{o p}$ is the operation time (s), and $\mathrm{E}_{\mathrm{f}}$ represents the conversion efficiency. 


\section{Results and discussion}

According to the National Energy Balance of Mexico (NEB), in 2013, primary energy production totalled 9,020.21 PJ. The petroleum continued as the main source of primary energy produced in the country. The energy produced from renewable sources was around $635.80 \mathrm{PJ}$ which represented 7.0\%. Biomass energy represented $59.65 \%$ of the renewable energy reported in the NEB 2013. This included only the sugarcane bagasse and wood with $379.26 \mathrm{PJ}$, which constitutes only $4.20 \%$ of the gross domestic supply of primary energy [19] (as is shown in fig. 2).

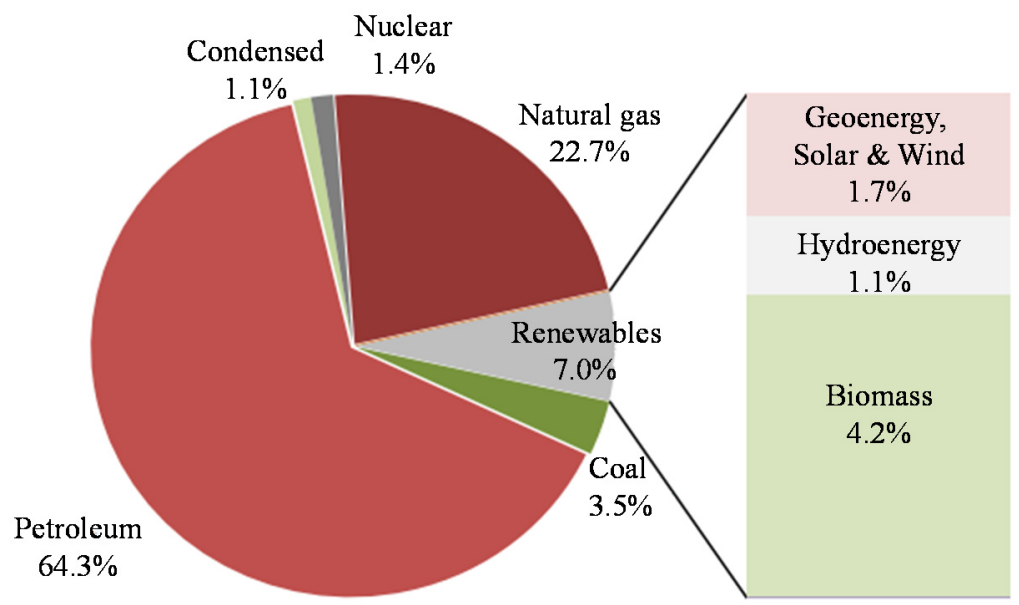

Figure 2: $\quad$ Primary energy production in Mexico, 2013 [19].

According to the data of the Energy Department of Mexico, biomass energy had an average participation of 359.19 PJ from 2001 to 2013. It was divided into 96.61 PJ of sugarcane bagasse and 262.58 PJ of wood (as is depicted in table 1).

The data of interest was processed and presented in fig. 3, which displays the main crops at national level. It is observed, that by 2013, the wheat crop was located in eight place, with a cultivated area of $634,240.99$ ha, which represents the $3.06 \%$ of the total agricultural harvested area.

The analysis of data indicates that Sonora has the biggest wheat crop area with $48.02 \%$ of the national participation, followed by Baja California with $13.67 \%$ (as can be seen in fig. 4). Only the states with more than one thousand hectares of wheat crop were considered in the current study.

Wheat straw is an important source of renewable energy, and it is available at the end of each agricultural cycle. A total of 4,612,950 t of wheat straw is 
Table 1: $\quad$ Breakdown energy in PJ of biomass since 2001 to 2013.

\begin{tabular}{|c|c|c|c|}
\hline Year & $\begin{array}{c}\text { Sugarcane } \\
\text { Bagasse }(\mathrm{PJ})\end{array}$ & $\begin{array}{c}\text { Wood } \\
(\mathrm{PJ})\end{array}$ & Total $(\mathrm{PJ})$ \\
\hline 2001 & 94.02 & 267.09 & 361.12 \\
\hline 2002 & 89.63 & 266.24 & 355.86 \\
\hline 2003 & 90.41 & 267.03 & 357.43 \\
\hline 2004 & 93.08 & 266.65 & 359.73 \\
\hline 2005 & 104.93 & 266.43 & 371.36 \\
\hline 2006 & 98.03 & 264.60 & 362.63 \\
\hline 2007 & 99.56 & 263.24 & 362.80 \\
\hline 2008 & 99.13 & 262.05 & 361.18 \\
\hline 2009 & 88.73 & 260.68 & 349.40 \\
\hline 2010 & 88.97 & 259.31 & 348.28 \\
\hline 2011 & 90.58 & 258.09 & 348.67 \\
\hline 2012 & 95.08 & 256.74 & 351.82 \\
\hline 2013 & 123.83 & 255.42 & 379.26 \\
\hline Average & 96.61 & 262.58 & 359.19 \\
\hline & & &
\end{tabular}

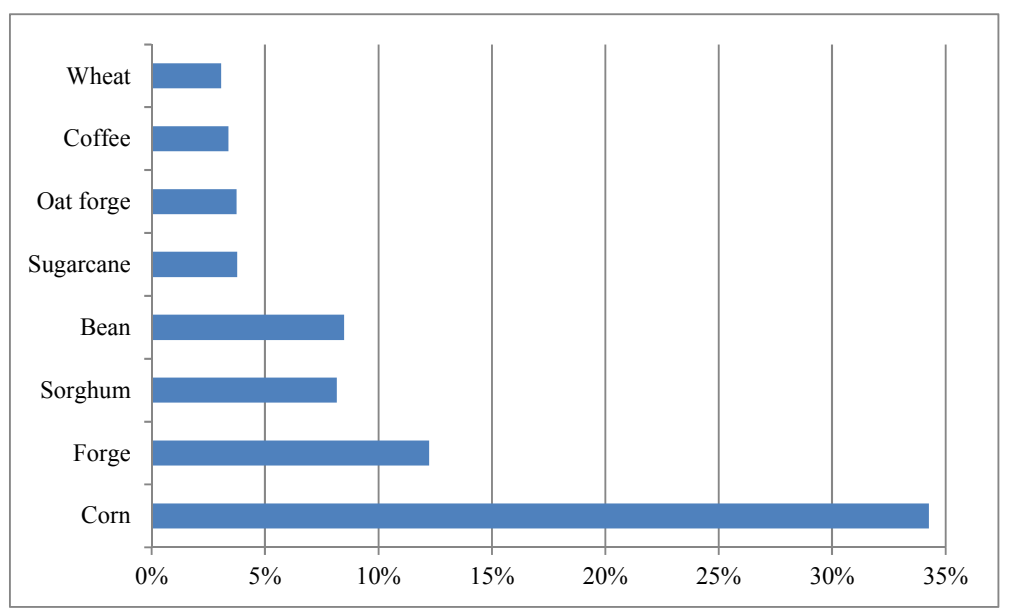

Figure 3: Distribution of agricultural area by crop in Mexico. 


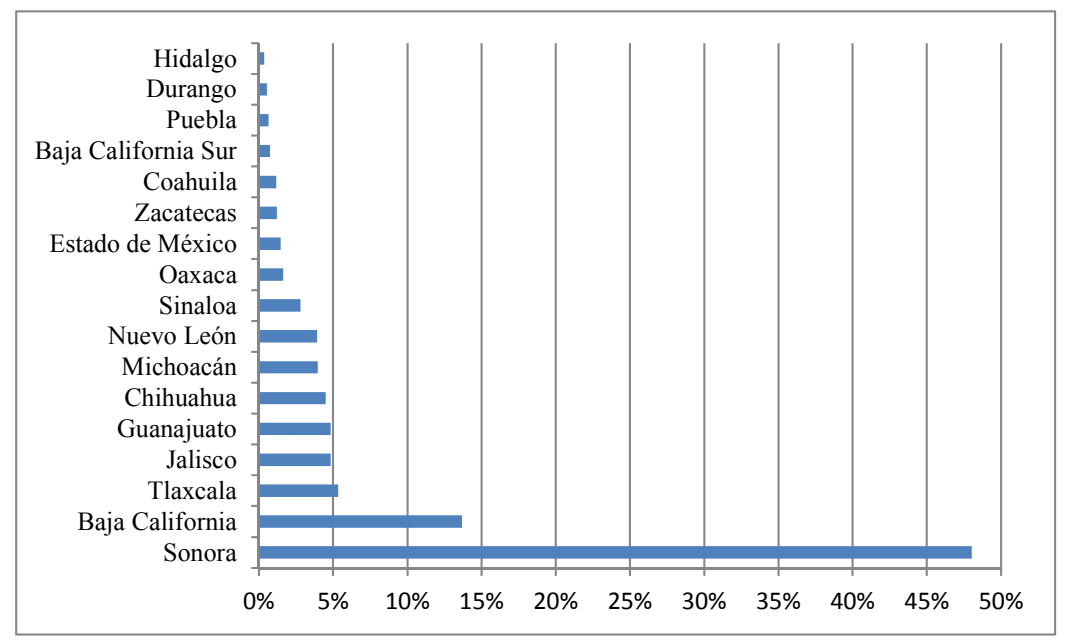

Figure 4: Main wheat crop producing states of Mexico.

Table 2: Generation potential of the main wheat producing states of Mexico.

\begin{tabular}{|c|l|c|c|c|c|}
\hline \multicolumn{1}{|c|}{ State } & $\begin{array}{c}\text { Wheat } \\
\text { harvested } \\
\text { area (ha) }\end{array}$ & $\begin{array}{c}\text { Wheat straw } \\
\text { generated (t) }\end{array}$ & $\begin{array}{c}\text { Energy } \\
(\mathrm{PJ})\end{array}$ & $\begin{array}{c}\text { Potential } \\
\text { electricity } \\
\text { generation } \\
\text { (MW) }\end{array}$ \\
\hline 1 & Sonora & $304,547.50$ & $2,223,196.75$ & 33.35 & 350.88 \\
\hline 2 & Baja California & $86,731.00$ & $633,136.30$ & 9.50 & 99.93 \\
\hline 3 & Tlaxcala & $33,912.00$ & $247,557.60$ & 3.71 & 39.07 \\
\hline 4 & Jalisco & $30,676.00$ & $223,934.80$ & 3.36 & 35.34 \\
\hline 5 & Guanajuato & $30,626.50$ & $223,573.45$ & 3.35 & 35.29 \\
\hline 6 & Chihuahua & $28,522.05$ & $208,210.97$ & 3.12 & 32.86 \\
\hline 7 & Michoacán & $25,213.07$ & $184,055.41$ & 2.76 & 29.05 \\
\hline 8 & Nuevo León & $24,876.20$ & $181,596.26$ & 2.72 & 28.66 \\
\hline 9 & Sinaloa & $17,670.57$ & $128,995.16$ & 1.93 & 20.36 \\
\hline 10 & Oaxaca & $10,324.00$ & $75,365.20$ & 1.13 & 11.89 \\
\hline 11 & Estado de México & $9,239.00$ & $67,444.70$ & 1.01 & 10.64 \\
\hline 12 & Zacatecas & $7,748.00$ & $56,560.40$ & 0.85 & 8.93 \\
\hline 13 & Coahuila & 7359.82 & $53,726.69$ & 0.81 & 8.48 \\
\hline 14 & Baja California Sur & $4,786.00$ & $34,937.80$ & 0.52 & 5.51 \\
\hline 15 & Puebla & $4,183.30$ & $30,538.09$ & 0.46 & 4.82 \\
\hline 16 & Durango & $3,365.17$ & $24,565.74$ & 0.37 & 3.88 \\
\hline 17 & Hidalgo & $2,130.81$ & $15,554.91$ & 0.23 & 2.46 \\
\hline & Total & $631,910.99$ & $4,612,950.23$ & 69.19 & 728.05 \\
\hline
\end{tabular}




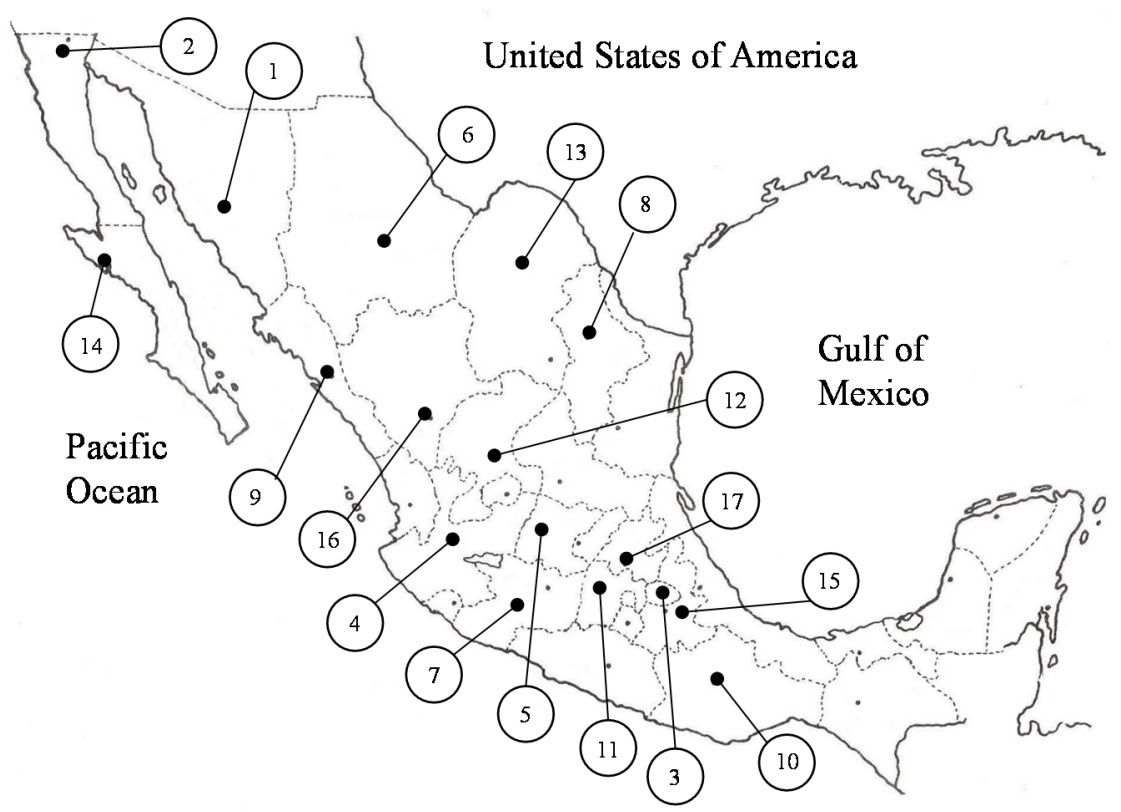

Figure 5: Electricity potential generation from wheat straw in Mexico.

generated in Mexico annually. An energy potential of 69.19 PJ per year was estimated. This magnitude of energy could be transformed into electricity, with a capacity of $720.05 \mathrm{MW}$, distributed in different wheat producing states (as shown in table 2 and illustrated geographically in fig. 5).

With the implementation of this proposal in Mexico, the contribution of the primary energy from biomass would be reflected in the NEB rising from 379.26 to $448.45 \mathrm{PJ}$; meaning an increment of $18.24 \%$.

\section{Conclusions}

In the search for new alternatives to eventually replace energy derived from oil; waste biomass is a feasible option. Moreover, energy generation powered by agriculture residues is a sustainable activity that does not deplete future resources. The harvest wheat activity does not only contribute to food security in Mexico, but also provides significantly biomass with a high energetic content.

One disadvantage of using this biomass waste is the transportation cost, hence, it is recommended that the wheat straw consumption is made as close to the source of biomass generation. In this way, the energetic diversification and sustainable development are supported through direct burning of wheat straw, without damaging the food and assisting in the reductions of air pollutants.

The results of this empirical study do not represent the only source for heat and power generation, it is necessary to incorporate other agricultural residues 
generated in the country. An important limitation is the localization of the power generation plants, because a long distance means lower economic benefits due to the cost of the transportation of wheat straw.

\section{References}

[1] Food and Agriculture Organization (FAO). 2012, Outlook Global Market Analysis. ISSN 0251-1959. www.fao.org/docrep/016/al993e/a1993e00.pdf

[2] Food and Agriculture Organization (FAO). 2013, Corporate Document Repository. Crop prospects and food situation, Global cereal supply and demand brief overview. www.fao.org/docrep/017/a1998e/a1998e.pdf

[3] Instituto Nacional de Estadística y Geografía (INEGI). 2013, Cuadro resumen, indicadores de demografía y población. www.inegi.org.mx

[4] Servicio de información agroalimentaria y pesca (SIAP). 2013, Anuario Estadístico de Producción Agrícola. www.siap.gob.mx/cierre-de-laproduccion-agricola-por-estado/

[5] Dooley, S. \& Treseder K., The effect of fire on microbial: a meta-analysis of field studies. Biogeochemistry, 109 (6) pp. 49-61, 2011.

[6] Johnston, F. Baillie, R. Pilotto, L. \& Hanigan, I., Ambient biomass smoke and cardio-respiratory hospital admissions in Darwin, Australia. MBC Public Health; 7(1):240, 2007.

[7] Haq, Z., 2001. Biomass for Electricity Generation. Citeseerx 2001. www.eia.gov/oiaf/analysispaper/biomass/pdf/biomass.pdf

[8] Demirbas, A., Biomass resource facilities and biomass conversion processing for fuels and chemicals. Energy Conversion and Management. 24(11), pp. 1357-1378, 2001.

[9] Simbolotti, G. 2007, Biomass for Power Generation and CHP. www.iea.org/techno/essentials3.pdf

[10] Muller, A., Sustainable agriculture and the production of biomass for energy use. Climatic Change, 94(3-4), pp. 319-331, 2008.

[11] Prompubess, C. Mekasut, L. Piumsomboon, P. \& Kuchontara, P., Cocombustion of coal and biomass in a circulating fluidized bed combustor. Korean Journal of Chemical Engineering, 24(6), pp. 989-995, 2007.

[12] Jurado, F. Cano, A. \& Carpio, J., Modelling of combined cycle power plants using biomass. Renewable energy, 28(1), pp. 743-753, 2003.

[13] National Renewable Energy Laboratory (NREL). Biopower. www.nrel.gov/learning/re_biopower.html

[14] National Renewable Energy Laboratory (NREL). Lessons Learned from Existing Biomass Power Plants. ww.nrel.gov/docs/fy00osti/26946.pdf

[15] Secretaria de Energía (SENER). 2006, Potenciales y viabilidad del uso del bioetanol y biodiesel para el transporte en México. www.sener.gob.mx/res/PE_y_DT/pub/Biocombustibles_en_Mexixo_Estu dio_Co mpleto.pdf

[16] McKendry, P., Energy production from biomass (part 1): overview of biomass. Bioresource Technology, 83(1), pp. 37-46, 2002. 
[17] Environmental Protection Agency (EPA). 2007, Combined Heat and Power Partnership. Biomass Combined Heat and Power Catalog of Technologies. www.epa.gov/chp/documents/biomass_chp_catalog.pdf

[18] D’Ovindio, A. \& Pagano M., Probabilistic multicriteria analyses for optimal biomass power plant design. Electric power system research, 79(1), pp. 645-652, 2009.

[19] Secretaria de Energía (SENER). 2014, Balance Nacional de Energía. www.energia.gob.mx/res/PE_y_DT/pub/2013/Balance_2013.pdf 